\title{
In memoriam prof.dr. Klaus E. Malten (1920-2009), emeritus hoogleraar arbeidsdermatologie, Radboud Universiteit Nijmegen
}

Op I 9 september 2009 overleed Klaus Malten, de eerste hoogleraar arbeidsdermatologie in Nederland. Malten werd aan de Universiteit van Amsterdam opgeleid tot dermatoloog in de dermatologische kliniek van professor Prakken. Prakken stimuleerde onderzoek op velerlei gebied, zo ook het onderzoek naar contacteczeem. De snelle ontwikkelingen in de jaren 50 van de $20 e$ eeuw op het gebied van kunststoffen leidde tot een uitbarsting van contacteczeem bij werknemers van vliegtuigbouwer Fokker. Dit leidde tot een uitgebreid onderzoek en het proefschrift waar Malten op promoveerde: Beroepsekzeem bij het verwerken van kunststoffen (I956). Na zijn opleiding tot dermatoloog kreeg hij een voltijdse researchaanstelling op het gebied van de arbeidsdermatologie bij het toenmalige Nederlands Instituut voor Praeventieve Geneeskunde TNO, in Leiden (I955I959). Daarna begon hij een praktijk in Arnhem en was als staflid verbonden aan de dermatologische afdeling van de R.K. Universiteit van Nijmegen. Het hoofd van deze afdeling, professor Mali, had een brede belangstelling en zag in de aanstelling van een arbeidsdermatoloog een be-

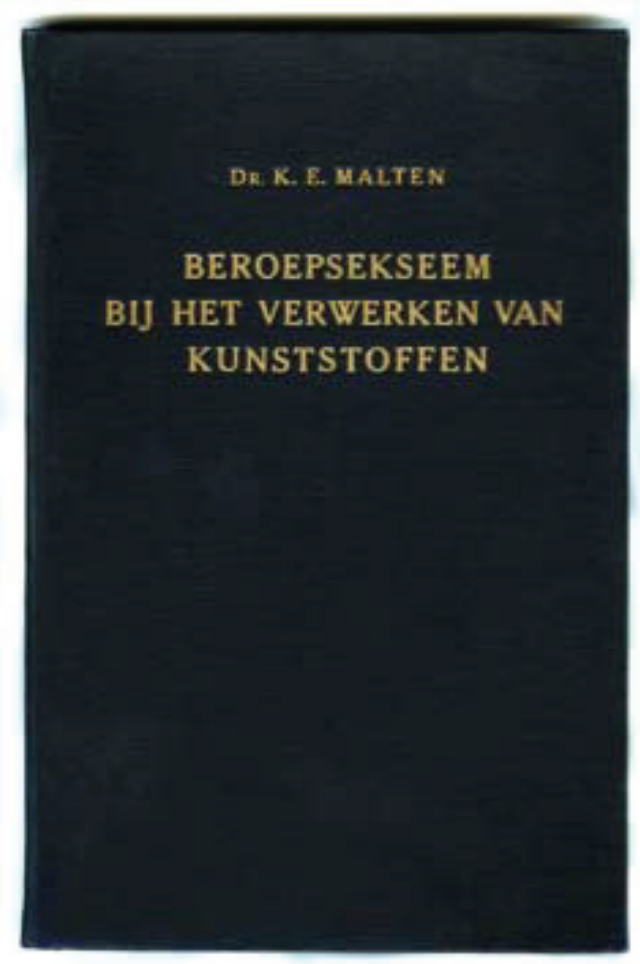

Proefschrift K.E. Malten (I956) langrijke uitbreiding van de mogelijkheden van zijn kliniek. In I962 werd hij benoemd tot lector, een benoeming die in I97I werd omgezet in een hoogleraarschap arbeidsdermatologie. De eerste in Nederland. Deze post bekleedde hij tot aan zijn pensionering in I985. Voor zijn verdiensten op het gebied van de arbeidsdermatologie en het belang voor de Nederlandse dermatologie kreeg hij de Mendes da Costa-penning van de Nederlandse Vereniging voor Dermatologie en Venereologie. De Nederlandse Vereniging voor Arbeidsen Bedrijfsgeneeskunde eerde hem met de G.C.E. Burgerpenning.

In Nijmegen ontwikkelde Malten de contactdermatologie tot een bloeiende tak met onder andere onderzoek op het gebied van hydratie van de huid. De plastics bleven hem boeien hetgeen resulteerde in een samenwerking met dr. R.L. Zielhuis, de latere hoogleraar bedrijfsgeneeskunde en hoofd van het Coronel Instituut in Amsterdam. Samen schreven zij het nog steeds lezenswaardige boek: Industrial Toxicology and Dermatology in the Production and Processing of

\section{Elsevier Monographs}

INDUSTRIAL TOXICOLOGY

AND DERMATOLOGY IN

THE PRODUCTION

AND PROCESSING

OF PLASTICS

nr

K. E. MALTEN

AND

R. L ZIEIHUIS

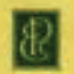

IISIVIEK

Boek geschreven met R.L. Zielhuis (I 964) 


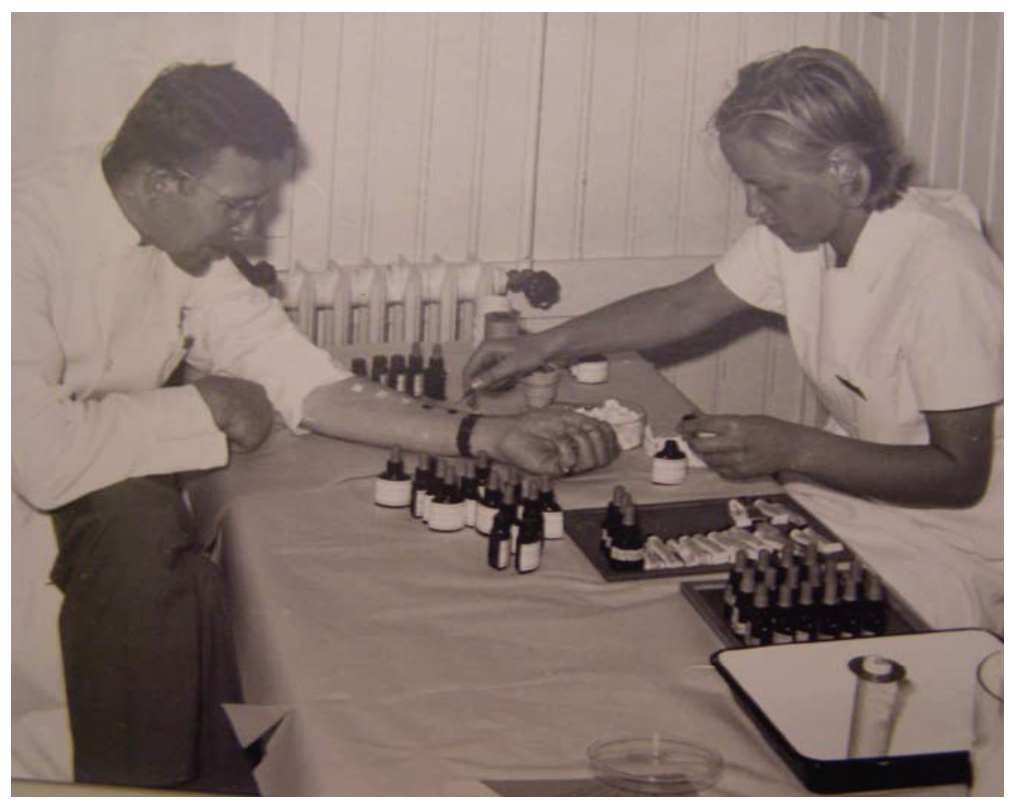

Klaus E. Malten in de periode van zijn proefschrift (1956). Met dank aan mevr. Flox den Hartog Jager-Malten voor het beschikbaar stellen van de foto.

Plastics (I964), gebaseerd op beider onderzoek bij Fokker. Hij schreef, samen met Nater en Van Ketel, voor de dermatoloog een klein maar fijn boek over de fijne kneepjes van het plakproefonderzoek: Patch Testing Guidelines (I976). Malten zag het belang van internationale banden en zocht contact met gelijkgerichten in Europa. En zo werd hij in I 967 mede-initiatiefnemer van wat het meest belangrijke internationale orgaan zou worden op gebied van contacteczeem, de International Contact Dermatitis Research Group. In datzelfde jaar startte de groep een nieuwsbrief Contact Dermatitis Newsletter - die later zou uitgroeien tot het nog steeds bestaande tijdschrift Contact Dermatitis. Malten zat vele jaren in de redactieraad van dit tijdschrift. In het eerste nummer van de newsletter staan twee bijdragen van Malten: Eczema Hybrids, over het samen voorkomen van atopisch en contacteczeem. De andere bijdrage ging over p-tertiarbutylphenol-hars in lijm. Vele publicaties zouden volgen. De belangrijkste is die over de door hem geponeerde en nog steeds gangbare hypothese over het cumulatieve effect van irriterende stimuli op de huid en het ontstaan van irritatief contacteczeem.

Na zijn pensionering trok hij zich terug uit de dermatologie en genoot hij van zijn veelvuldige verblijf in de Provence.

Prof.dr. D.P. Bruynzeel, emeritus hoogleraar arbeidsdermatologie, VUmc Amsterdam. Bestuurslid Nederlandse Vereniging voor Klinische Arbeidsgeneeskunde 